International Journal of Environment, Agriculture and Biotechnology
Vol-7, Issue-1; Jan-Feb, 2022
JJEAB
$\begin{gathered}\text { Journal Home Page Available: } \text { https://ijeab.com/ } \\ \text { Journal DOI: } 10.22161 / \text { ijeab }\end{gathered}$

Peer Reviewed

\title{
Combined Effects of Nitrogen, Mulch and Gibberellic Acid on Postharvest Physiology of Multi-Purpose Pumpkin Leaves and Fruits
}

\author{
D.K. Isutsa*, M.M. Mwaura
}

Department of Plant Sciences, Chuka University, P. O. Box 109-60400, Chuka

Email: profdkisutsa@gmail.com, disutsa@chuka.ac.ke, margretmwaura@gmail.com

* Corresponding Author email: profdkisutsa@gmail.com

Received: 30 Dec 2021; Received in revised form: 11 Feb 2022; Accepted: 19 Feb 2022; Available online: 28 Feb 2022

(C)2022 The Author(s). Published by Infogain Publication. This is an open access article under the CC BY license

(https://creativecommons.org/licenses/by/4.0/).

\begin{abstract}
The leaves, fruits and seeds of multi-purpose pumpkin (Cucurbita moschata Duch.) species are consumed as vegetables, snacks and blended dishes to boost household health, food and nutritional security. However, cultivation without using inputs leads to poor postharvest physiological attributes. Consequently, a study was conducted to assess the effects of combined nitrogen, mulch and gibberellic $\operatorname{acid}\left(G_{3}\right)$ on postharvest physiology of pumpkin. The treatments comprised fourN rates $(0,50,100$ and $150 \mathrm{~kg} \mathrm{~N} / \mathrm{ha}$ )supplied as CAN, three mulch types (none, unpainted, andblack-painted rice straws) and three $\mathrm{GA}_{3}$ rates $(0,40$ and $80 \mathrm{mg} / \mathrm{L})$. Experimentation was done in two seasons using split-split plots arranged in randomized complete block design with three replications, and $2 m \times 2 m$ plant spacing. Nitrogen occupied main plots, mulch sub-plots, and GA 3 split plots. Post-harvest measures reported in this paper were harvested edible leaf weight, leaf and fruit moisture losses. Data values were subjected to analysis of variance using SAS Version 9.3. Separation of significant means was done using the least significant difference test at $\alpha=0.05$.Nitrogen fertilizer did not significantly $(P>0.05)$ affect leaf weight and physiological weight loss, but it significantly $(P<0.05)$ increased fruit physiological weight loss. Mulch had no significant effect on leaf weight and physiological weight loss, but it significantly increased fruit physiological weight loss. The effect of $\mathrm{GA}_{3}$ on leaf weight and physiological weight losses was not significant, although the trend was positive in fruits. Similarly, combined nitrogen, mulch and GA3 did not significantly affect leaf weight and physiological weight losses in both seasons. Thus, the increase of weight loss in pumpkin fruits produced using high nitrogen, mulch or $\mathrm{GA}_{3}$ application should be counteracted by taking appropriate postharvest deterrent measures. On the other hand, the influence of combined nitrogen, mulch and $\mathrm{GA}_{3}$ on multi-purpose pumpkin performance cannot be entirely depicted by analysing postharvest physiology.
\end{abstract}

Keywords-Cucurbita moschata, Leaf weight, Physiological weight loss, Shrinkage, Shriveling.

\section{INTRODUCTION}

Pumpkin is an important, healthy food crop, which isrich in vitamins, minerals and antioxidants, but low in calorific content, making it weight-loss-friendly (Kiharason et al., 2017). Its nutrients and antioxidants are good boosters of the immune system, protectors of eyesight, reducers ofcertain cancer risks, and promoters of heart and skin health (Ghanbari et al., 2007).Proper pumpkin growth, production, development and physiology require integration of inputs. However, growers often concentrate on application of sole inputs at unverified rates, leading to poor nourishment that does not benefit post harvest physiology.Poor postharvest physiology leads to lessor wastage of produce before it is utilised as food or for income generation.This is despite the fact that the increased demand of pumpkin produce can only be 
fulfilled by using integrated inputs that enhance postharvest physiology.

Nitrogen is an essential element in plant growth. Although $\mathrm{NH}_{4}{ }^{+}, \mathrm{NO}_{2}{ }^{-}$and $\mathrm{NO}_{3}{ }^{-}$account for less than $5 \%$ of the total $\mathrm{N}$ in the soil, Liu et al. (2014) indicated that $\mathrm{N}$ is a critical element that most plants absorb. Nitrogen is the most important element for proper plant growth and development, which substantially increases and enhances yields and quality, as it plays a critical role in biochemical and physiological processes (Ullah et al., 2010). Nitrogen enhances total leaf biomass which is a determinant of pumpkin leaf vegetable yield (Nasim et al., 2012). Mulch prevents soil leaching and runoff of fertilizer, conserves soil moisture, increases soil temperature, suppresses weeds and prevents pathogen splash, thereby enhancing growth, yield, quality and shelf-life of pumpkin leaves, fruits and seeds (Cerniauskiene et al., 2015). Endogenous gibberellins help transport water and nutrients through the xylem and influence many biochemical and physiological processes like photosynthesis, respiration, protein synthesis, cell extension, wall thickness and stability (Abbas et al., 2011), which are important in productivity and quality enhancement. Gibberellins strengthen parthenocarpic flowers and fruits to prevent abortion, which is common in pumpkins particularly when pollination is inadequate (Mwaura et al., 2014; Isutsa and Mwaura, 2017; Kiramana and Isutsa, 2019).

Sub-optimal inputs contribute to poor returns through high post-harvest loss (Nakazibwe et al., 2019). According to Kader (2013), food security can be enhanced through reduction of post-harvest loss and increase ofproduceshelflife. Some procedures that can be carried out include using cultivars with long shelf life, integrated crop management systems that promote yield, quality and postharvest stability, as well as appropriate pre-harvest and postharvest handling procedures that sustain physiology, quality and safety of crops and their products (Kitinoja et al., 2011).

Promoting postharvest physiology through integrated input management practices will guarantee pumpkin yields and income increment for producers, as well as food and nutrition security boost for households and consumers (Gomez et al., 2020). Owing to the increasing need of pumpkin produce in Kenya, coupled with the challenge of ensuring that it is plentiful and remains wholesome, determining optimal inputs for enhancing postharvest physiology is very imperative. The present paper determined the interactive effects of nitrogen fertiliser, mulch and $\mathrm{GA}_{3}$ in enhancing preharvest physiology of pumpkin leaves and fruits.

\section{MATERIALS AND METHODS}

\subsection{Research Site}

The present experiment was conducted from January 2019 to August 2020 in two seasonal trials. Season 1 ran from March 2019 to July, 2019 with 1,004.3 mm rainfall, and Season 2 ran from October 2019 to February 2020 with $1,259.6 \mathrm{~mm}$ rainfall. The research site lies at $0^{\circ} 19^{\prime} \mathrm{S}$, $37^{\circ} 38^{\prime} \mathrm{E}$ and $1535 \mathrm{~m}$ above sea level. The average annual temperature is $19.5^{\circ} \mathrm{C}$ derived from $12.2^{\circ} \mathrm{C}$ to $23.2^{\circ} \mathrm{C}$. The research area experiences two rainy seasons with the long rains occurring from March to June and short rainsfrom October to December (Jaetzold et al., 2006). The average annual rainfall is $1200 \mathrm{~mm}$ (http://en.climate-data.org). The soils are humic nitisols, deep, strongly weathered, well drained with a clayey subsurface horizon and high cation exchange capacity (Koskey et al., 2017).

\subsection{Experimental Design and Treatments}

The experiment used three-factorplots embedded in randomized complete block design with three replications. Each experimental plot measured $2 \mathrm{~m} \times 2 \mathrm{~m}$ and was separated from others by 1 mspace. The three factors tested were nitrogen, mulch and $\mathrm{GA}_{3}$ assigned to mainplots, sub-plots and split-plots, respectively. Nitrogen was applied as CAN to provide0, 50, 100 and $150 \mathrm{~kg} \mathrm{~N} / \mathrm{ha}$. The amount of CAN fertilizer used per experimental unit was calculated as: a) $50 \mathrm{~kg} \mathrm{~N} / \mathrm{ha}=76.9 \mathrm{~g} \mathrm{CAN} / 4 \mathrm{~m}^{2}$; b) $100 \mathrm{~kg}$ $\mathrm{N} / \mathrm{ha}=153.8 \mathrm{~g} \mathrm{CAN} / 4 \mathrm{~m}^{2}$; c) $150 \mathrm{~kg} \mathrm{~N} / \mathrm{ha}=230.7 \mathrm{~g}$ $\mathrm{CAN} / 4 \mathrm{~m}^{2}$. Nitrogen fertilizer was applied as two equal doses at four weeks from seedling emergence and at the beginning of flowering.

Mulch applied was none, unpainted and black-painted rice straws easily available in a close proximity to the experimental site and quantities required. The blackpainted dry rice straws and unpainted dry rice straws were placed on their respective plots after land preparation. Painting of the rice straws was done by dipping them in a 200-L drum containing black paint solution and spreading out on the soil to air-dry. The rice straws were uniformly spread on the soil to achieve $20 \mathrm{~cm}$ thickness. Planting holes were marked and opened in rice straw mulch during pumpkin seed sowing.

The $\mathrm{GA}_{3}$ rates were $0 \mathrm{mg} / \mathrm{L}, 40 \mathrm{mg} / \mathrm{L}$ and $80 \mathrm{mg} / \mathrm{L}$. The $\mathrm{GA}_{3}$ granules were dissolved in $50 \mathrm{ml}$ alcohol and then the volume made up to one litre stock solution by adding distilled water. The required concentration of spray solution was then prepared from the stock solution by diluting with distilled water. A few drops of commercial sticker were added to the solutions to facilitate uptake of the $\mathrm{GA}_{3}$ into leaves. The $\mathrm{GA}_{3}$ was sprayed onto plants using a 1-L hand-held sprayer. Spray solution with low $\mathrm{GA}_{3}$ rate was applied first followed by next high rate. 
Spraying was done once during the fourth week after emergence. To avoid chemical drift, spraying was done during a calm morning while observing wind direction.

\subsection{Pumpkin Establishment and Management}

Three multipurpose pumpkin fruits of uniform size, free from disease and insect pests, and from one mother plant were used. The fruits were sourced from farmers endorsed by Extension Officer near the research site. Seeds were prepared as recommended to handle pumpkin seeds for planting and used immediately after extraction (AOAC, 1995).

The field was prepared to appropriate tilth required for pumpkin growth. All recommended phosphorus and potassium straight fertilizers were applied just before seed sowing. Two seeds were placed at the centre of each planting hole and one seedling was uprooted two weeks after emergence. All plots were kept weed-free through rogueing and manual cultivation. Irrigation was done using drip tubes to supplement rain during drought. Insect pest and disease control was done when appropriate using recommended pesticides and rates. The vines were coiled when they became long,while leaving them in contact with the soil. Data values were taken from all plants for experimentation, except those in guard rows.

\subsection{Data Collection and Analysis}

Data was collected as described below for the two experimental seasons.Dry matter accumulation was measured on two vegetable leaf samples per experimental unit. The two leaves were oven-dried at $60^{\circ} \mathrm{C}$ until a constant weight was achieved. Picking of edible leaves was done at the $3^{\text {rd }}$ and $4^{\text {th }}$ internode on three randomly selected branches per plant. Harvesting was done by cutting the leaf stalk with a knife ensuring that each leaf had a $15 \mathrm{~cm}$ stalk. The first, second, third and fourth leaf harvesting was done three, four, five and six weeks after leaf production, respectively (Mwaura et al., 2014). Close monitoring was done to enable marking of the identified leaves at production. Special markers with different colours to represent each treatment were used. The harvested leaves were weighed on a balance scale and assessed for dry matter using themethod described by Windham et al. (1987). Three leaves were left at the tip of each branch to allow growth to continue. The measured fresh weight of the vegetable leaves was recorded in grams.

Weight loss was determined by weighing and recording leaves and fruits. Three leaves per treatment harvested at the $6^{\text {th }}$ node of two previously marked branches were used. The first weight measurement was taken at harvesting. Leaves were then weighed after every two (2) days until a constant weight was achieved and the weight recorded in grams. Three (3) fruits per treatment were weighed at harvesting and the weight recorded as initial weight in $\mathrm{kg}$. Fruits were weighed once per week for 6 weeks. Subsequent weekly measurements for fruits and day measurements for leaves were treated as the weight in the tested week/day. Physiological weight loss was calculated as a percentage of the initial weight using the equation: $\mathrm{WL}(\%)=\left(\left(\mathrm{W}_{\mathrm{o}}-\mathrm{W}_{\mathrm{i}}\right) / \mathrm{W}_{\mathrm{o}}\right) \times 100$; Where $\mathrm{W}_{\mathrm{o}}$ is weight on the first day of storage and $\mathrm{Wi}$ is the weight in the tested day (Moalemiyan and Ramaswamy, 2012).Data values on leaf weight, leaf and fruit physiological weight losses were subjected to analysis of variance, using the SAS software version 9.3. Mean separation was performed using the least significant difference test at $\alpha=0.05$.

\section{RESULTS AND DISCUSSION}

\subsection{Effectof Nitrogen on Leaf Weight and Physiological Weight Loss}

Nitrogen had no significant $(P>0.05)$ effect on leaf weight (Figure 1). The $150 \mathrm{~kg} \mathrm{~N} /$ ha had highest leaf weight of 17.21g and $16.59 \mathrm{~g}$ in S1 and S2, respectively. Leaf weight increased with increase in nitrogen up to $150 \mathrm{~kg} \mathrm{~N} / \mathrm{ha}$. Nonitrogen produced the lowest leaf weight of $15.40 \mathrm{~g}$ and $15.08 \mathrm{~g}$ in $\mathrm{S} 1$ and $\mathrm{S} 2$, respectively. Nitrogen had a significant $(P>0.05)$ effect on leaf physiological weight loss in both seasons. The $150 \mathrm{~kg} \mathrm{~N} / \mathrm{ha}$ had the highest leaf physiological weight loss of $6.90 \mathrm{~g}$ and $6.73 \mathrm{~g}$ inS1 and S2, respectively. Physiological weight loss increased with increase in nitrogen up to $150 \mathrm{~kg} \mathrm{~N} / \mathrm{ha}$ in both seasons. No nitrogen produced physiological weight loss of $5.50 \mathrm{~g}$ and $5.60 \mathrm{~g}$ in $\mathrm{S} 1$ and $\mathrm{S} 2$, respectively. Nitrogen had a significant $(P<0.05)$ effect on fruit physiological weight loss in S2 only. The $150 \mathrm{~kg} \mathrm{~N} /$ ha produced the highest physiological weight lossof $1.05 \mathrm{~g}$ and 0.82 gin $\mathrm{S} 1$ and $\mathrm{S} 2$, respectively. Fruit physiological weight loss increased with increase in nitrogen up to $150 \mathrm{~kg} \mathrm{~N} / \mathrm{ha}$. The control had the lowest fruit physiological weight loss of $0.89 \mathrm{~g}$ and $0.62 \mathrm{~g}$ in $\mathrm{S} 1$ and $\mathrm{S} 2$, respectively.

The findings of the present study were similar to those of Yildirim et al. (2007), who found that head and leaf dry matter of broccoli were negatively affected by nitrogen and foliar urea. In their study, urea statistically and significantly decreased the head dry matter content. Sorensen (1999) and Balik et al. (2003) reported that increasing nitrogen amounts in growth of broccoli, cabbage and maize resulted in lower dry matter percentages in leaves, stems and heads. These responses could be attributed to high succulent growth, as opposed to dense growth.

3.2. Effect of Mulch on Leaf Weight and Physiological Weight Loss 
Mulch had no significant $(P>0.05)$ effect on leaf weight of multi-purpose pumpkin fruits during both seasons as shown in Figure 2. Nevertheless, application of black-painted rice straw mulch produced the highest leaf weight of $17.39 \mathrm{~g}$ and $16.03 \mathrm{~g}$ during $\mathrm{S} 1$ and $\mathrm{S} 2$, respectively. In both seasons, lowest leaf weight of $15.29 \mathrm{~g}$ and $15.78 \mathrm{~g}$ for $\mathrm{S} 1$ and $\mathrm{S} 2$, respectively, was obtained when unpainted rice straw mulch was applied.

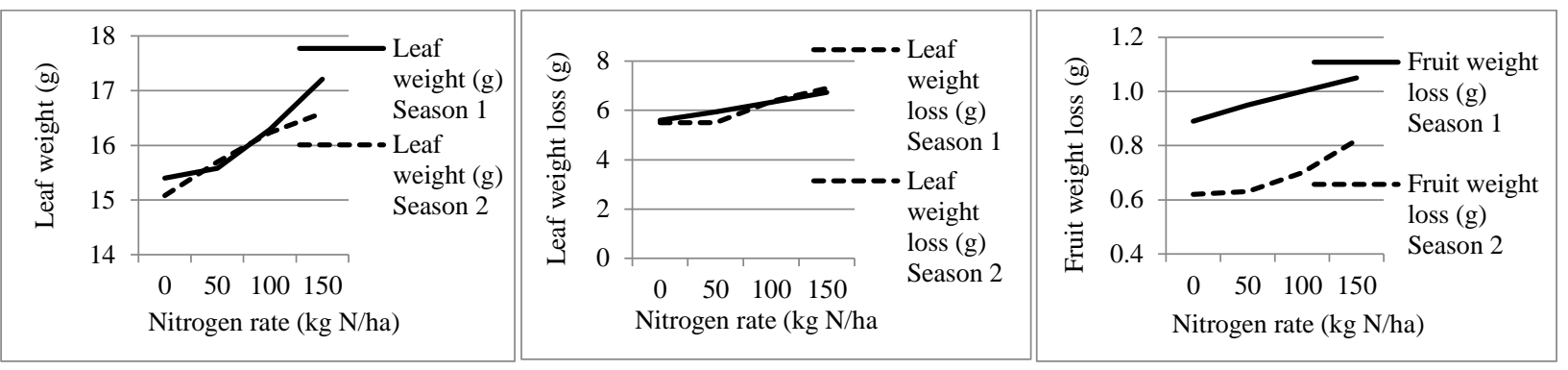

Fig.1: Effect of nitrogen on leaf weight and physiological weight loss. Season 2 fruit weight loss $P=0.031, L S D_{0.05}=0.13$

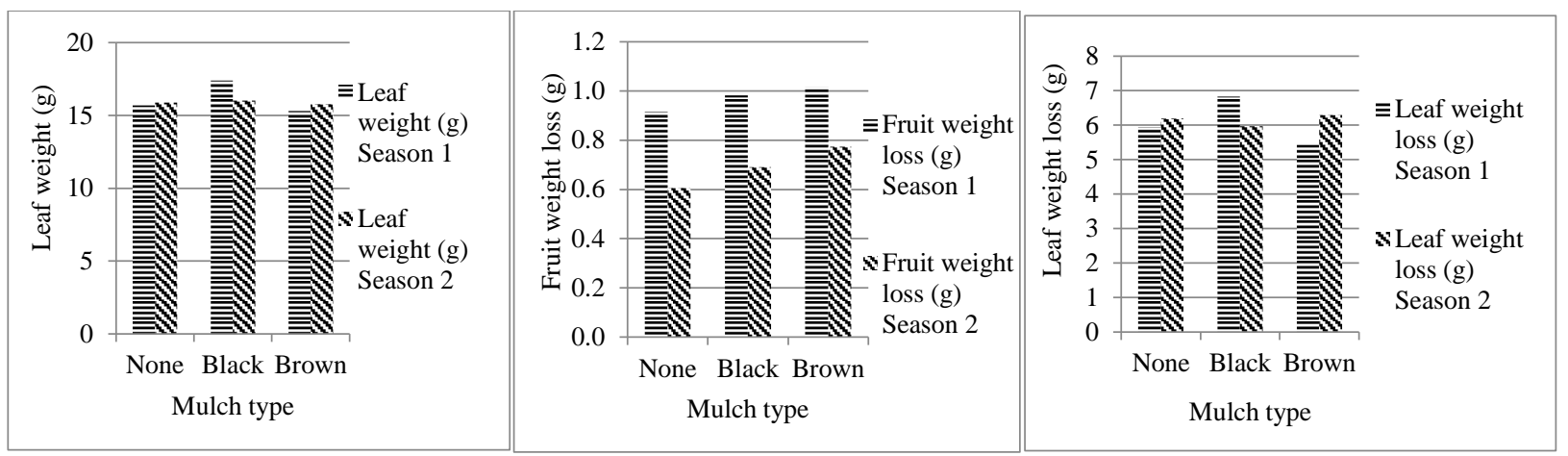

Fig.2: Effect of mulch on leaf weight and physiological weight loss. Season 2 fruit weight loss $P=0.001, L S D_{0.05}=0.047$

Mulch had no significant $(P>0.05)$ effect on physiological weight loss in both seasons. Black-painted rice straws had the highest leaf physiological weight loss of $6.83 \mathrm{~g}$ in $\mathrm{S} 1$, while no mulch had the highest leaf physiological weight loss of $6.19 \mathrm{~g}$ in $\mathrm{S} 2$. Mulch had a significant $(P<0.05)$ effect on leaf physiological weight loss of fruits in $\mathrm{S} 2$, but the effect was not significant $(P>0.05)$ in $\mathrm{S} 1$. Fruit physiological weight loss was lowest $0.915 \mathrm{~g}$ and $0.606 \mathrm{~g}$ in $\mathrm{S} 1$ and $\mathrm{S} 2$, respectively, while use of unpainted rice straw mulch produced the highest leaf physiological weight loss of $1.015 \mathrm{~g}$ and $0.774 \mathrm{~g}$ during $\mathrm{S} 1$ and $\mathrm{S} 2$, respectively (Figure 2).

The lack of significant effect of mulch on leaf weight and physiological weight loss in both seasons was similar to that reported by Helaly et al. (2017) in Physalispubescens. On the contrary, Israt (2018) and Ibarra-Jimenez et al. (2008) found a significant effect of mulch on dry matter in squash and physiological weight of cucumber. The variation may be due to the different crop species and environments assessed.

\subsection{Effects of GA3on Leaf Weight and Physiological Weight Loss}

There was no significant $(P>0.05)$ effect of $\mathrm{GA}_{3}$ on leaf weight in both seasons (Figure 3). Leaf weight of $17.16 \mathrm{~g}$ and $16.35 \mathrm{~g}$ in $\mathrm{S} 1$ and $\mathrm{S} 2$, respectively, was highest when no $\mathrm{GA}_{3}$ was applied. Leaf weight was lowest $15.54 \mathrm{~g}$ when 80 $\mathrm{mg} / \mathrm{L} \mathrm{GA}{ }_{3}$ was applied in $\mathrm{S} 1$ and $15.13 \mathrm{~g}$ when $40 \mathrm{mg} / \mathrm{L}$ $\mathrm{GA}_{3}$ was applied in $\mathrm{S} 2 . \mathrm{GA}_{3}$ had no significant $(P>0.05)$ effect on leaf physiological weight loss in both seasons. No $\mathrm{GA}_{3}$ produced the highest physiological weight loss of 7.03 $\mathrm{g}$ in $\mathrm{S} 1$, while highest physiological weight loss of $6.58 \mathrm{~g}$ was obtained when $40 \mathrm{mg} / \mathrm{L} \mathrm{GA} \mathrm{GA}_{3}$ was applied in $\mathrm{S} 2$. Physiological weight loss decreased as the $\mathrm{GA}_{3}$ was increased in $\mathrm{S} 1$.

The $\mathrm{GA}_{3}$ had no significant effect on physiological weight loss in both seasons. The $40 \mathrm{mg} / \mathrm{L} \mathrm{GA}_{3}$ fruit physiological weight loss was lowest $0.960 \mathrm{~g}$ and $0.667 \mathrm{~g}$ in $\mathrm{S} 1$ and $\mathrm{S} 2$, respectively (Figure 3 ). Fruit physiological weight loss of $0.989 \mathrm{~g}$ and $0.710 \mathrm{~g}$ in $\mathrm{S} 1$ and $\mathrm{S} 2$, respectively, was highest when $40 \mathrm{mg} / \mathrm{L} \mathrm{GA}_{3}$ was applied. 


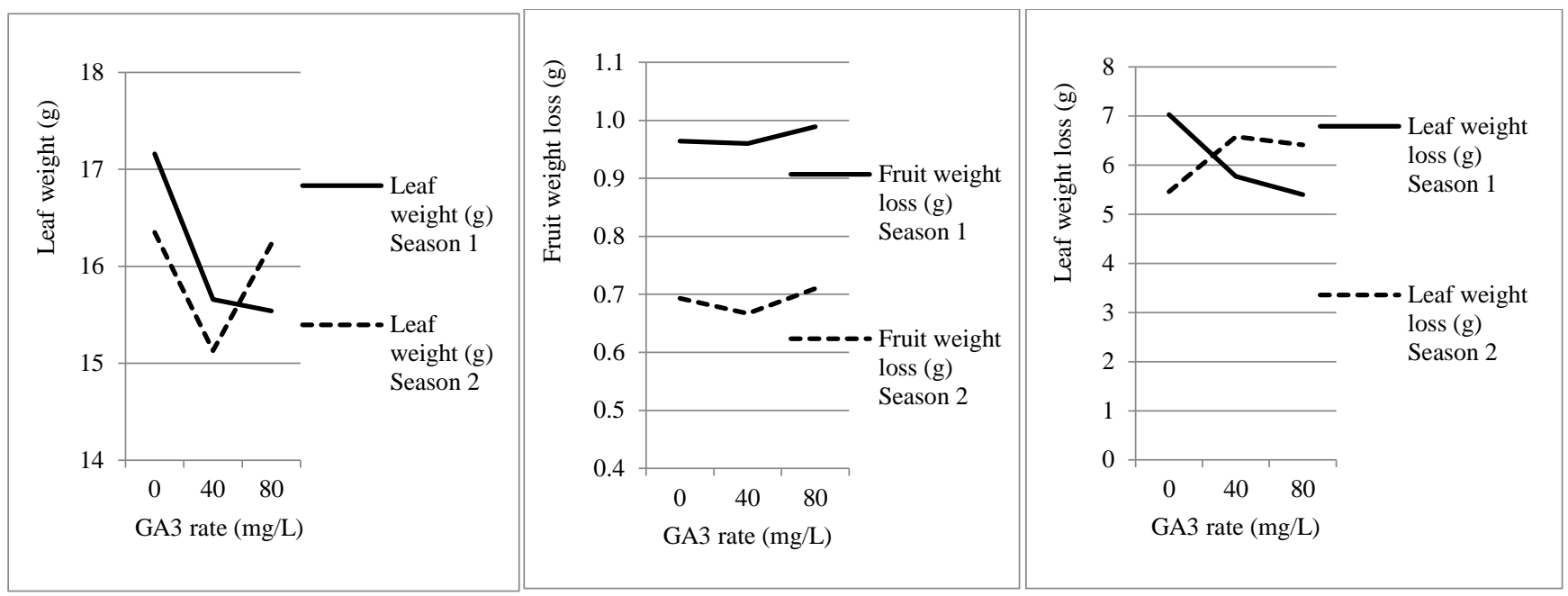

Fig.3: Effect of $\mathrm{GA}_{3}$ on leaf weight and physiological weight loss

Application of $\mathrm{GA}_{3}$ reduced the leaf weight in this study which contradicts the results of Shafeek et al. (2016), who reported increased leaf weight and significant effect in squash plants. Physiological weight loss in both the leaves and fruits was low when $\mathrm{GA}_{3}$ was applied during season 1 , but during season 2, application of $\mathrm{GA}_{3}$ increased physiological weight loss in both the leaves and fruits. Growth regulators were found to improve the physiological performance of sweet cherry (Correia et al., 2020). The lack of consistency in seasonal responses is attributed to climatic variations that may be beyond the control of researchers. Regardless, the low leaf weight and high postharvest physiological weight loss could be attributed to promotion of more succulent growth in pumpkin by the applied $\mathrm{GA}_{3}$ (Abbas et al., 2011).

\subsection{Effect of Nitrogen, Mulch and GA3on Leaf Weight and Physiological Weight Loss}

The highest leaf weight of $21.23 \mathrm{~g}$ for $\mathrm{N}_{3} \mathrm{M}_{1} \mathrm{GA}_{0}$ and 20.23 $\mathrm{g}$ for $\mathrm{N}_{2} \mathrm{M}_{0} \mathrm{GA}_{1}$, while the lowest of $10.98 \mathrm{~g}$ for $\mathrm{N}_{2} \mathrm{M}_{0} \mathrm{GA}_{2}$ and 11.10 gfor $\mathrm{N}_{0} \mathrm{M}_{0} \mathrm{GA}_{2}$ were recorded in $\mathrm{S} 1$ and $\mathrm{S} 2$, respectively (Table 1 ). The $\mathrm{N}_{3} \mathrm{M}_{1} \mathrm{GA}_{0}(150 \mathrm{~kg}$ $\mathrm{N} /$ ha, black-painted rice straw mulch and $0 \mathrm{mg} / \mathrm{L} \mathrm{GA}_{3}$ ) and $\mathrm{N}_{2} \mathrm{M}_{0} \mathrm{GA}_{0}\left(100 \mathrm{~kg} \mathrm{~N} / \mathrm{ha}\right.$, no mulch and $\left.0 \mathrm{mg} / \mathrm{L} \mathrm{GA}_{3}\right)$ had the highest interactive effect on leaf weight in $\mathrm{S} 1$ and $\mathrm{S} 2$, respectively. No significant effect of interaction was observed in S1 and S2 on pumpkin leaf weight.

The highest leaf physiological weight loss of 10.27 gwas for $\mathrm{N}_{2} \mathrm{M}_{0} \mathrm{GA}_{0}$, while the lowest of $1.30 \mathrm{~g}$ was for $\mathrm{N}_{2} \mathrm{M}_{0} \mathrm{GA}_{2}$ in $\mathrm{S} 1$. In $\mathrm{S} 2$, highest leaf physiological weight loss of $10.27 \mathrm{~g}$ was for $\mathrm{N}_{3} \mathrm{M}_{2} \mathrm{GA}_{0}$, while the lowest of 2.20 $\mathrm{g}$ was for $\mathrm{N}_{3} \mathrm{M}_{0} \mathrm{GA}_{0}$. The $\mathrm{N}_{2} \mathrm{M}_{0} \mathrm{GA}_{0}(100 \mathrm{~kg} \mathrm{~N} / \mathrm{ha}$, no mulch and $0 \mathrm{mg} / \mathrm{LGA}_{3}$ ) and $\mathrm{N}_{3} \mathrm{M}_{2} \mathrm{GA}_{0}(150 \mathrm{~kg} \mathrm{~N} / \mathrm{ha}$, unpainted rice straw mulch and $0 \mathrm{mg} / \mathrm{L} \mathrm{GA}_{3}$ ) had the highest interactive effect on leaf physiological weight loss in S1 and S2, respectively. No significant effect occurred due to interactive effect in both seasons (Table 1).

Fruit physiological weight loss was highest $1.38 \mathrm{~g}$ for $\mathrm{N}_{2} \mathrm{M}_{0} \mathrm{GA}_{2}$, while the lowest of $0.52 \mathrm{~g}$ was for $\mathrm{N}_{3} \mathrm{M}_{0} \mathrm{GA}_{2}$ in S1 (Table 1). Highest fruit physiological weight loss of $1.00 \mathrm{~g}$ was for $\mathrm{N}_{3} \mathrm{M}_{1} \mathrm{GA}_{2}$, while $\mathrm{N}_{1} \mathrm{M}_{0} \mathrm{GA}_{0}$ had the lowest of $0.50 \mathrm{~g}$ in $\mathrm{S} 2$ (Table 1). The $\mathrm{N}_{2} \mathrm{M}_{0} \mathrm{GA}_{2}(100 \mathrm{~kg} \mathrm{~N} / \mathrm{ha}$, no mulch and $\left.80 \mathrm{mg} / \mathrm{L} \mathrm{GA}_{3}\right)$ and $\mathrm{N}_{3} \mathrm{M}_{1} \mathrm{GA}_{2}(150 \mathrm{~kg} \mathrm{~N} / \mathrm{ha}$, black-painted rice straw mulch and $80 \mathrm{mg} / \mathrm{L} \mathrm{GA}_{3}$ ) had the highest interactive effect in $\mathrm{S} 1$ and $\mathrm{S} 2$, respectively. No significant effect was observed due to interactive effect on physiological weight loss in both seasons.

The results of the interactive effect that showed no significant effect were similar to those reported by Tsiakaras et al. (2014) on leaf weight of lettuce. Nonetheless, significant interactive effect of $\mathrm{GA}_{3}$ and $\mathrm{N}$ on leaf weight of brussel sprouts has been reported (Selman and Bora, 1999). The reported results contrasted probably because of different crop species and two factors tested. The increase in physiological weight loss may be attributed to increased accumulation of moisture in produce during production under high rates of nitrogen, mulch and $\mathrm{GA}_{3}$, which is then available for loss after harvest of produce. 
Table 1: Effect of nitrogen, mulch and GA3on leaf weight and physiological weight lossin pumpkin leaves and fruits

\begin{tabular}{|c|c|c|c|c|c|c|}
\hline \multirow[t]{2}{*}{ Treatment } & \multicolumn{2}{|c|}{ Leaf weight (g) } & \multicolumn{2}{|c|}{ Leaf weight loss (g) } & \multicolumn{2}{|c|}{ Fruit weight loss (g) } \\
\hline & S1 & $\mathrm{S} 2$ & S1 & S2 & S1 & $\mathrm{S} 2$ \\
\hline $\mathrm{N}_{0} \mathrm{M}_{0} \mathrm{GA}_{0}$ & 18.14 & 14.67 & 9.65 & 5.00 & 0.72 & $(0.50)$ \\
\hline $\mathrm{N}_{0} \mathrm{M}_{1} \mathrm{GA}_{0}$ & 14.82 & 15.35 & 4.83 & 6.03 & 0.98 & 0.77 \\
\hline $\mathrm{N}_{0} \mathrm{M}_{2} \mathrm{GA}_{0}$ & 17.69 & 16.38 & 7.70 & 6.37 & 0.78 & 0.57 \\
\hline $\mathrm{N}_{0} \mathrm{M}_{0} \mathrm{GA}_{1}$ & 13.59 & 18.45 & 3.60 & 8.43 & 0.88 & $(0.50)$ \\
\hline $\mathrm{N}_{0} \mathrm{M}_{1} \mathrm{GA}_{1}$ & 19.60 & 14.74 & 9.60 & 4.77 & 1.10 & 0.67 \\
\hline $\mathrm{N}_{0} \mathrm{M}_{2} \mathrm{GA}_{1}$ & 12.20 & 11.50 & 2.90 & 3.47 & 0.97 & 0.70 \\
\hline $\mathrm{N}_{0} \mathrm{M}_{0} \mathrm{GA}_{2}$ & 13.19 & (11.10) & 3.53 & 2.43 & 0.88 & 0.60 \\
\hline $\mathrm{N}_{0} \mathrm{M}_{1} \mathrm{GA}_{2}$ & 16.96 & 18.40 & 3.63 & 8.40 & 0.77 & 0.63 \\
\hline $\mathrm{N}_{0} \mathrm{M}_{2} \mathrm{GA}_{2}$ & 14.07 & 15.10 & 4.07 & 5.47 & 0.88 & 0.62 \\
\hline $\mathrm{N}_{1} \mathrm{M}_{0} \mathrm{GA}_{0}$ & 14.74 & 14.89 & 4.73 & 4.90 & 0.68 & $(0.50)$ \\
\hline $\mathrm{N}_{1} \mathrm{M}_{1} \mathrm{GA}_{0}$ & 18.10 & 13.44 & 8.10 & 4.43 & 0.70 & 0.87 \\
\hline $\mathrm{N}_{1} \mathrm{M}_{2} \mathrm{GA}_{0}$ & 13.35 & 12.32 & 3.33 & 2.23 & 1.13 & 0.63 \\
\hline $\mathrm{N}_{1} \mathrm{M}_{0} \mathrm{GA}_{1}$ & 15.18 & 17.13 & 5.17 & 7.47 & 0.83 & 0.52 \\
\hline $\mathrm{N}_{1} \mathrm{M}_{1} \mathrm{GA}_{1}$ & 15.67 & 15.04 & 5.67 & 5.07 & 0.95 & 0.65 \\
\hline $\mathrm{N}_{1} \mathrm{M}_{2} \mathrm{GA}_{1}$ & 16.16 & 16.37 & 6.17 & 6.80 & 1.12 & 0.55 \\
\hline $\mathrm{N}_{1} \mathrm{M}_{0} \mathrm{GA}_{2}$ & 13.74 & 19.40 & 4.40 & 9.37 & 1.05 & 0.57 \\
\hline $\mathrm{N}_{1} \mathrm{M}_{1} \mathrm{GA}_{2}$ & 18.28 & 17.30 & 8.30 & 7.63 & 0.92 & 0.65 \\
\hline $\mathrm{N}_{1} \mathrm{M}_{2} \mathrm{GA}_{2}$ & 13.36 & 15.40 & 3.70 & 5.43 & 1.13 & 0.70 \\
\hline $\mathrm{N}_{2} \mathrm{M}_{0} \mathrm{GA}_{0}$ & 20.25 & 14.05 & 10.27 & 4.40 & 1.07 & 0.63 \\
\hline $\mathrm{N}_{2} \mathrm{M}_{1} \mathrm{GA}_{0}$ & 17.96 & 15.48 & 7.93 & 5.80 & 1.25 & 0.77 \\
\hline $\mathrm{N}_{2} \mathrm{M}_{2} \mathrm{GA}_{0}$ & 15.84 & 17.50 & 5.83 & 7.50 & 0.87 & 0.65 \\
\hline $\mathrm{N}_{2} \mathrm{M}_{0} \mathrm{GA}_{1}$ & 16.29 & 20.23 & 6.30 & 10.2 & 0.92 & 0.65 \\
\hline $\mathrm{N}_{2} \mathrm{M}_{1} \mathrm{GA}_{1}$ & 18.27 & 16.32 & 8.27 & 6.33 & 0.77 & 0.73 \\
\hline $\mathrm{N}_{2} \mathrm{M}_{2} \mathrm{GA}_{1}$ & 14.36 & 16.20 & 4.70 & 6.23 & 0.97 & 0.67 \\
\hline $\mathrm{N}_{2} \mathrm{M}_{0} \mathrm{GA}_{2}$ & (10.98) & 15.80 & (1.30) & 6.10 & 1.38 & 0.67 \\
\hline $\mathrm{N}_{2} \mathrm{M}_{1} \mathrm{GA}_{2}$ & 17.30 & 14.50 & 7.30 & 4.50 & 1.08 & 0.75 \\
\hline $\mathrm{N}_{2} \mathrm{M}_{2} \mathrm{GA}_{2}$ & 15.35 & 16.00 & 5.33 & 5.93 & 1.17 & 0.78 \\
\hline $\mathrm{N}_{3} \mathrm{M}_{0} \mathrm{GA}_{0}$ & 17.53 & 11.23 & 7.53 & $(2.20)$ & 1.08 & 0.73 \\
\hline $\mathrm{N}_{3} \mathrm{M}_{1} \mathrm{GA}_{0}$ & 21.23 & 16.25 & 7.90 & 6.23 & 1.18 & 0.93 \\
\hline $\mathrm{N}_{3} \mathrm{M}_{2} \mathrm{GA}_{0}$ & 16.26 & 19.95 & 6.57 & 10.27 & 1.12 & 0.77 \\
\hline $\mathrm{N}_{3} \mathrm{M}_{0} \mathrm{GA}_{1}$ & 14.56 & 15.73 & 4.87 & 5.73 & 0.97 & 0.73 \\
\hline $\mathrm{N}_{3} \mathrm{M}_{1} \mathrm{GA}_{1}$ & 14.92 & 17.07 & 4.93 & 7.10 & 1.07 & 0.87 \\
\hline $\mathrm{N}_{3} \mathrm{M}_{2} \mathrm{GA}_{1}$ & 17.09 & 17.36 & 7.07 & 7.37 & 0.98 & 0.77 \\
\hline $\mathrm{N}_{3} \mathrm{M}_{0} \mathrm{GA}_{2}$ & 19.97 & 18.10 & 9.97 & 8.03 & $(0.52)$ & 0.67 \\
\hline $\mathrm{N}_{3} \mathrm{M}_{1} \mathrm{GA}_{2}$ & 15.55 & 15.40 & 5.53 & 5.37 & 1.02 & 1.00 \\
\hline $\mathrm{N}_{3} \mathrm{M}_{2} \mathrm{GA}_{2}$ & 17.76 & 18.30 & 7.77 & 8.30 & 1.07 & 0.88 \\
\hline$P$-value & 0.102 & 0.720 & 0.195 & 0.773 & 0.540 & 0.917 \\
\hline LSD $5 \%$ & 6.440 & 7.606 & 6.098 & 6.931 & 0.472 & 0.241 \\
\hline
\end{tabular}

S1= Season 1 (March 2019-July 2019); S2= Season 2 (October 2019-February 2020).

Bolded values $=$ Highest Bracketed values $=$ Lowest 


\section{CONCLUSION AND RECOMMENDATION}

Nitrogen fertilizer does not significantly affect leaf weight and physiological weight loss, but it significantly increases fruit physiological weight loss. Mulch has no significant effect on leaf weight and physiological weight loss, but it significantly increases fruit physiological weight loss. The effect of $\mathrm{GA}_{3}$ on leaf weight and physiological weight lossis not significant, although the trend is positive on weight loss. Similarly, combined nitrogen, mulch and $\mathrm{GA}_{3}$ consistently do not have a significant effect on leaf weight and physiological weight losses. Thepresent study indicates thatthe increase of weight loss in pumpkin fruits produced using high nitrogen, mulch or $\mathrm{GA}_{3}$ application should be counteracted by taking appropriate postharvest deterrent measures. On the other hand, the influence of combinednitrogen, mulch and $\mathrm{GA}_{3}$ onmulti-purpose pumpkin performance cannot be wholly depicted by analysing postharvest physiology.

\section{REFERENCES}

[1] Abbas, G., Aslam M., Malik, A.U., Abbas Z., Ali, M., and Hussain F. (2011). Potassium sulphate effects on growth and yield of mung bean (Vigna radiata L.) under arid climate. International Journal of Agriculture and Applied Science, 3, 72-75.

[2] AOAC. (1995). Official Methods of Analysis of the AOAC International, (16 ${ }^{\text {th }}$ edition). Method 970.12. Association of Official Analytical Chemists International. Washington, DC.

[3] Balik, J., Cerny J., Tlustos, P., andZitkova, M. (2003). Nitrogen balance and mineral nitrogen content in the soil in a long experiment with maize under different systems of $\mathrm{N}$ fertilization. Plant Soil Environment, 49, 554-559

[4] Cerniauskiene, J., Kulaitiene, J., Danilcenko, H., and Jariene, E. (2015). Mulch impact on the quality of oil pumpkin (Cucurbita pepo L.) fruit. Journal ofFood, Agriculture and Environment, 10(1), 245-247.

[5] Correia, S., Queiros, F., Ferreira, H., Morais, M. C. et al. (2020). Foliar application of calcium and growth regulators modulate sweet cherry (Prunus avium L.) tree performance. Plants, 9, 1-15, 410.

[6] Ghanbar, A., Nadjali, F., and Shabahang, J. (2007). Effects of irrigation regimes and row arrangement on yield, yield components and seed quality of pumpkin. Asian Journal of Plant Sciences, 6(7), 1072-1079.

[7] Gomez, P. S., Riesgo, L., \&Louhichi, K. (2020). The Role of Smallholder Farms in Food and Nutrition Security. 10.

[8] Helaly, A. A., Goda, Y., El-Rehim, A. A. S., Mohamed, A. A., and El-Zeiny, O. A. H. (2017).Effect of polyethylene mulching type on the growth, yield and fruits quality of Physalis pubescens. Advances in Plants and Agriculture Research, 6(5), 1-7.

[9] Ibarra-Jimenez L., Zermeno-Gonzalez A., Munguia-Lopez J., Quezada-Martin M.A.R., and de La Rosa-Ibarra M. (2008). Photosynthesis, soil temperature and yield of cucumber as affected by coloured plastic mulch. Acta Agricultural Scand. BSP, 58, 372-378.

[10] Israt, J. S. (2018). Effect of mulch materials and nitrogen on growth and yield of squash. Research Thesis, Sher-e-Bangla Agricultural University.

[11] Isutsa, D. K., and Mwaura, M.M. (2017). Effects of irrigation rate and leaf harvest intensity on multi-purpose pumpkin (Cucurbita moschata Duch.) growth and quality. International Journal of Development and Sustainability, 6(9), 1121-1141.

[12] Jaetzold R., Schmidt, H., Hornetz, B., and Shisanya C. (2006). Farm Management Handbook of Kenya. Vol. II Natural Conditions and Farm Management Information $2^{\text {nd }}$ Edition Part B Central Kenya. Subpart B2. Central Province.

[13] Kader, A.A. (2013). Post-harvest technology of horticultural crops: Overview from Farm to Fork. Ethiopian Journal of Applied Science and Technology, 1(1), 1-8.

[14] Kiharason, J. W., Isutsa, D. K. and Ngoda, P. N. (2017a). Nutritive value of bakery products prepared from wheat and pumpkin composite flour. Global Journal of Bioscience and Biotechnology, 6(1), 96-102.

[15]Kiramana, J. K. and Isutsa, D. K. 2019. Determination of factors influencing cultivation and utilization of pumpkins among smallholders in Kakamega and Nyeri Counties in Kenya. East African Agricultural and Forestry Journal.83(1):34-48.

[16] Kitinoja, L., Saran, S., Roy, S.K., and Kader, A.A. (2011). Post-harvest technology for developing countries: Challenges and opportunities in research, outreach and advocacy. Journal of Science, Food and Agriculture, 2(91), 597-606.

[17] Koskey, G., Mburu, S., Njeru, E., Kimiti, J., Ombori, O. and Maingi,J.. (2017). Potential of native rhizobia in enhancing nitrogen fixation and yields of climbing beans (Phaseolus vulgaris L.) in contrasting environments of Eastern Kenya. Front. Plant Sci. 8, 443..

[18]Liu, C., Sung, Y., Chen, B., and Lai, H. (2014). Effects of nitrogen fertilizers on the growth and nitrate content of lettuce (Lactuca sativa L.). International Journal of Environmental Research and Public Health, 11, 4427-4440.

[19] Moalemiyan, M., and Ramaswamy, H. S. (2012). Quality retention and shelf-life extension in Mediterranean cucumbers coated with a pectin-based film. Journal of Food Research, 1(3), 159-168.

[20] Mwaura, M.M., Isutsa, D.K., Ogweno, J.O., and Kasina, M. (2014). Interactive effects of irrigation rate and leaf harvest intensity on edible leaf and fruit yields of pumpkin (Cucurbita moschata Duch). International Journal of Science and Nature, 5(2), 199-204.

[21] Nasim, W., Ahmad A., Hammad, H.M., Chaudhary, H. J., and Munis, M.F.H. (2012). Effect of nitrogen on growth and yield of sunflower under semi-arid conditions of Pakistan. Pakistan Journal of Botany, 44(2), 639-648.

[22] Selman, I. W., and Bora, P. C. (1999). The effects of gibberellic acid and nutrient sprays on growth and yield of brussels sprout. Annals of Applied Biology, 61(1), 131-138. 
[23] Shafeek, M. R., Helmy, Y. I., Ahmed, A. A., and Ghoname, A. A. (2016). Effect of foliar application of growth regulators ( $\mathrm{GA}_{3}$ and Ethereal) on growth, sex expression and yield of summer squash plants (Cucurbita pepo L.) under plastic house condition. International Journal of ChemTech Research, 9(6), 70-76.

[24] Sorensen, J. N. (1999). Nitrogen effects on vegetable crop production and chemical composition. In: Proc. Workshop Eco. Asp. Veg. Fertil. Integr. Crop Prod. Field. Acta Horticulture, 506, 41-49.

[25] Tsiakaras, G., Petropoulos, S., and Khah, E. (2014). Effect of $\mathrm{GA}_{3}$ and nitrogen on yield and marketability of lettuce.Australian Journal of Crop Science, 8(1), 127-132.

[26] Ullah, M.A., Anwar, M., and Rana, A.S. (2010). Effect of nitrogen fertilization and harvesting intervals on the yield and forage quality of elephant grass under mesic climate of Pothowar Plateau. Pakistan Journal of Agricultural Science, 47, 231-234.

[27] Windham, W.R., Robertson, J. A., and Leffler, R.G. (1987). A comparison of methods for moisture determination of forages for near infrared reflectance spectroscopy calibration and validation. Crop Science, 27,777-783.

[28] Yildirim, E., Guvenc, I., Turan, M., andKaratas, A. (2007). Effect of foliar urea application on quality, growth, mineral uptake and yield of broccoli (Brassica oleracea L., var. Italica). Plant soil environment, 53(3), 120-128. 